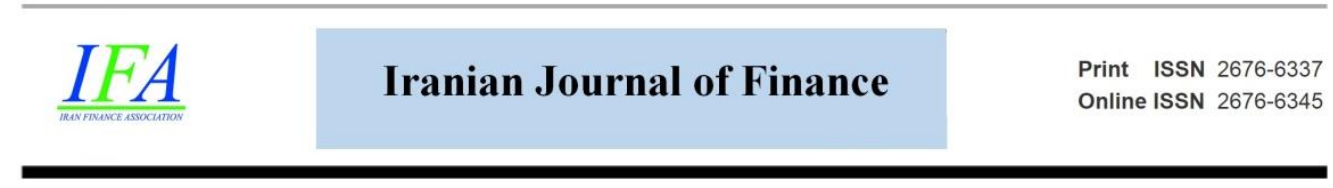

\title{
Dynamic correlation between exchange rate and the listed industries stock index during the currency crises: The Implications for Optimal Portfolio Construction
}

\section{Maryam Bazraei}

PhD Candidate in Islamic Economy, Department of Economics, Firoozkooh Branch, Islamic Azad University, Firoozkooh, Iran. (Email: maryambazraei@yahoo.com)

\section{Salleh Ghavidel}

Department of Economics, Firoozkooh Branch, Islamic Azad University, Firoozkooh, Iran. (Email: salleh_mogh@yahoo.com)

\section{Ghodratollah Emamverdi*}

*Corresponding Author, Department of Economics, Central Tehran Branch, Islamic Azad University, Tehran, Iran. (Email: ghemamverdi@iauctb.ac.ir)

\section{Mahmoud Mahmoudzadeh}

Department of Economics, Firoozkooh Branch, Islamic Azad University, Firoozkooh, Iran. (Email: mahmod.ma@yahoo.com)

Document Type: Original Article

Received: 2021/05/28
2021, Vol. 5, No. 4. 25-51.

Published: 2021/12/05

\begin{abstract}
In this study, we examine the correlation between stock returns of Exportoriented (EOIs) and Import-oriented (IOIs) industries and exchange rates, to derive stock-exchange optimal weights, attempting to manage the risk of investors in the capital market. To do so, the ADCC and DCC models are used. The data consists of the stock return of the listed industries, and the daily exchange rate from 2008 to 2020. The results suggest that EOIs have a dynamic asymmetric conditional correlation, and IOIs have a dynamic
\end{abstract}


symmetric conditional correlation with the exchange rate. Moreover, the results indicate that in both currency crises, the weight of optimal portfolio in all industries except pharmaceuticals, in non-crisis period is over $50 \%$ and in the crisis period is less than $50 \%$. Accordingly, and to reduce the risk of the portfolio, in the non-crisis period, investors should invest more than half of a one-Rial portfolio to dollar exchange, and in the crisis period, they should allocate less than half of a one-Rial portfolio to this currency. In case of the currency crisis, it is suggested that investors invest in the stock of basic metals, because this industry is a pioneer in attracting currency crisis and increasing stock value of the industry through future cash flow and replacement value, and reduce the stock of pharmaceuticals and computers in their portfolio, due to attracting negative effects of the exchange market.

JEL: G10, F31, G11, C58

Keywords: Stock market, Exchange rate, Optimal portfolio, Dynamic conditional correlation

DOI: https://doi.org/10.30699/IJF.2021.278675.1210 Publisher: Iran Finance Association

Copyright: author(s) Type of License: Creative Commons License (CC-BY 4.0)

\section{Introduction}

The complexity of financial markets and their interconnections make a loss in a sector or a country spread rapidly to other sectors of the economy of other countries. The empirical evidence has shown that markets are not separated from each other and their movements will not take place in an isolated space. Then, fluctuations in different asset markets are strongly related to each other and understanding the relationship between financial assets is necessary for investors in order to make better decisions.

Securities and exchange markets have ever been the sensitive parts of financial markets. These two markets rapidly absorb fluctuations in commercial cycles of the economy and reflect the economic changes. At the same time, distress in one or two markets creates concerns among policymakers and investors. The dynamic interaction between these two markets has encouraged researchers, policymakers and analysts to conduct accurate detailed analyses. Despite the lack of consensus in theory about the interaction between stock prices and exchange rate, it should be noted that the mediating variables such as wealth, demand for money and interest rates play significant roles in the establishment of such linkages (Saleh, 2008). 
Financial markets suddenly change their behavior and the resulting behavior for most of the asset prices remains the same for a long period of time. During certain periods like financial crisis, the average, instability and correlation patterns in asset returns reveal dramatic changes. Recessions and booms in financial markets will lead to an increased likelihood of abnormal movements in the market which couldn't be ignored by labeling them as outliers. Since the summer of 2011 and due to imposed economic sanctions, unilaterally withdrawal of the United States from the joint comprehensive plan of action, liquidity growth during many years and other factors, the Iranian economy has witnessed an unprecedented situation. After a long period of controlling the exchange rate, the market experienced instability, leading to considerable fluctuations in other financial markets. The Record-breaking Tehran Stock Index began in 2012 and reached its peak in July 2020. As a result of the recessions in economic activities and high inflation, stock market or foreign exchange market as alternatives for investments were ahead of investors who had hot money ${ }^{1}$ in their hands.

In such turmoil in the mentioned asset markets, the questions are: had the exchange rate fluctuations strong asymmetric correlations with the stock price of export and import-oriented industries ${ }^{2}$ over the time? Which of the listed industries will have the highest weight in the optimal portfolio?

Diversification, hedging and risk management are not possible without a good deal of knowledge on behavior and relationship between targeted assets, and finding answers for aforementioned questions can provide a clear insight about analysis and prediction of return assets developments and using them to make appropriate investment policies.

To achieve our goals, this paper is organized into five sections: introduction, literature review, methodology, findings, and finally, conclusion and remarks.

\footnotetext{
${ }^{1}$ Hot money refers to the flow of funds from one market to another in order to earn high short-term profits.

${ }^{2}$ Export-oriented industries included in this study are basic metals, metallic minerals, chemicals, oil products and cement. Daily numerical values of their indices were used as data in the analysis. As these industries export a portion of their products and receive the common currency of importing countries (dollar or euro), they are significantly affected by exchange rate fluctuations. Importoriented industries included in this study are pharmaceuticals, computers and car industries. Daily numerical values of their indices were used as data in the analysis. As these industries import their raw materials or pre-manufactured parts and products during the production process, they need outlay of foreign exchange and thus are significantly affected by fluctuations of foreign exchange. Among these industries, pharmaceuticals have the highest volume of raw materials import.
} 


\section{Literature Review}

So far, no consensus is reached on the dynamic relationship between exchange rate and stock price, so that two attitudes could be distinguished in this regard: Dornbusch and Fisher (1980) by developing flow-oriented models assume that a country's current account and current balance are two important determinants of the exchange rate. Accordingly, changes in the exchange rate affect international competitiveness and balance of trade and then it may affect real variables of the economy such as real production and income, the firms' future and current liquidity flow and thus the stock price. This model suggests that depreciation of local currency (increased exchange rate) makes the local firms more competitive and their exporting goods become cheaper at the international level. The increased advantage of domestic products and consequently, higher exports lead to higher income which will increase the firms' stock price on its own. Then in these models, the exchange rate affects stock price in a positive direction.

Another attitude is stock-oriented models. These models assume that capital account mainly determines the exchange rate. They are composed of a portfolio balanced model and a monetary model. In the portfolio balanced model, Branson (1983) posits that there is a negative relationship between exchange rate and stock price. Accordingly, decreases in a stock price reduce the wealth of local investors, leading to lower demand for money with ensuing lower interest rates. Lowering the interest rate encourages the capital outflow, ceteris paribus, and causes depreciation of local currency and appreciation of foreign exchange rate. In the monetary model of Gavin (1989), as opposed to the aforementioned models, there is no relationship between exchange rate and stock price. Therefore, with regard to these three models, it could be concluded that theoretical studies have not come to a clear outcome on the relationship between the exchange market and stock price. On the other hand, Bhattacharya and Mukherjee (2002) theory suggests that until the 1950s risk was considered a qualitative factor and then it was Markowitz efforts that made the risk quantifiable and standard deviation of cash flows in different conditions was introduced as risk measurement quantity. He postulated that investors do not necessarily look for maximization of expected return, because if they do, they will only choose the asset with the maximum expected return; but in practice, investors own a portfolio containing different securities and thus, they compare different investments with respect to expected return (average return) and standard deviation (squared variance), picking out the best investment. As the exchange rate is an integral part of a portfolio, Markowitz theory implies that 
the rate of this asset may affect its demand and subsequently, causes changing the stock price. For example, in case of depreciation of exchange rate, the product costs will be reduced and as result, the profit margin will change in a positive direction (Heidari\&Bashiri, 2012). Therefore, investors get to change their attitude on risk management. Many hedging strategies are emerging in an attempt to respond to this question that how other markets may be used for purpose of hedging. Given that the ways of finding optimal portfolio weights have become a critical problem for investors, making a portfolio to hedge with other assets like foreign exchange, gold, oil and so on has found its way as a risk management strategy. In addition, volatility spillover between two markets is essential to build hedge ratios and optimal portfolios (Chang et al, 2011). According to previous studies, it is important to estimate optimal hedge ratio and portfolio weights, such that investors have more information while adopting hedge strategy (Huisman et al, 2009; Yao \& Wu, 2012).

Researchers have studied the relationship between exchange rate and the stock market, using numerous methods, to find an appropriate approach for the implementation of hedging strategies in these markets. For example, Yousaf et al (2021) examine the hedging role of gold against Asian stock markets during the Covid-19 outbreak. Their results suggest that during the Covid-19 outbreak, gold is an appropriate asset to hedge stock prices in most Asian stock markets ${ }^{3}$. The optimal weights of gold-stock portfolios are lower during the Covid-19 sub-periods than the pre-Covid-19 period. As result, investors should increase their investment in gold during the Covid-19 sub-period. Hedging effectiveness for most Asian stock markets is higher during the Covid-19 sub-period.

Akhtaruzzaman et al (2021) investigate financial contagion through financial and non-financial firms between China and G7 countries during the Covid-19 pandemic. Their results suggest that financial and non-financial firms have experienced a significant increase in the conditional relationship between their stock returns. Moreover, the magnitude of increase in correlations is significantly higher for financial firms during the Covid-19 outbreak, highlighting the importance of their role in financial contagion. They show that optimal weights ratios increase considerably in most of the cases, implying higher costs of hedging during the Covid-19 outbreak.

Arash Habibi \& Chin Lee (2019) investigate asymmetric effects of exchange rate on stock prices in G7 countries (Canada, France, Germany, Italy, Japan, United Kingdom and the United States) during 1997-206; and for this

\footnotetext{
${ }^{3}$ China, Indonesia, Singapore, Vietnam, Pakistan and Thailand stock markets
} 
purpose, they use NARDL model. They show that in all G7 countries, change of exchange rate has an asymmetric short-term effect on stock prices; while in the long-term, this result is not true, except for Germany.

Simona Moagar-Poladian et al (2019) examine the linkage between exchange rates and stock markets in four Central and Eastern European (CEE) countries using the DCC-MIDAS model. The estimates suggest significant differences between correlation patterns in four sample countries. Moreover, they find a relatively low degree of convergence among exchange rates markets in CEE.

Sosa et al (2018) analyze the dynamic links between the stock market and exchange rate in MILA countries (Colombia, Chile, Mexico, and Peru) using Markov Switching-Autoregressive and Markov Switching-Vector Autoregressive models. The results reveal that stock returns in these countries evolve according to low volatility and high volatility regimes. Moreover, the effect of stock markets on exchange rates is more than the effect of the exchange rate on stock markets. These results confirm that contagion exists between stock markets and exchange rates in Peru and Chile.

Wang et al (2016) examined whether gold was used to hedge against the global exchange rate. Their results revealed that exchange rate fluctuations result in threshold effects and influence the gold hedging effectiveness.

Arouri et al (2015) studied the relationship between world gold prices and stock return in China to develop hedging and diversification strategies using multivariate GARCH. They analyzed optimal weights and hedge ratios for stock and gold and indicated that how empirical results could be used to adopt a hedging strategy.

Basher et al (2015) investigate the conditional correlation between emerging markets of stock, oil price, VIX, gold price and bonds using DCC, ADCC and GO-GARCH. The results suggest that in most situations, oil is the best hedge for stock prices in emerging markets. The hedge ratios resulted from ADCC is preferred over other methods to hedge emerging markets stock prices with oil, VIX or bonds. In some cases, hedge ratios resulted from GOGARCH have the highest hedging effectiveness to hedge emerging markets stock prices with gold.

Yen-Hesien-Lee et al (2014) examine portfolio construction between the stock price of G7 countries and West Texas Intermediate crude oil. In addition, to study volatility spillovers between stock price and oil price with DCC, CCC and BEKK models, they obtain optimal portfolio weights. The results suggest 
that the hedge effectiveness of the DCC model is better than the CCC model and BEKK model, and the hedging effect in Canada is the highest and it is lowest in Japan. Moreover, the results show that Japan has the biggest optimal portfolio weight and the lowest hedge ratio.

Elmi et al (2014) investigate the effect of structural breaks in volatilities on momentum transfer and volatility spillover between gold and stock markets in Iran over a period of 2007-2013, using the conventional iterated cumulative sum of squares (ICSS) algorithm, as well as modified iterated cumulative sum of squares algorithm. The results suggest that momentum and volatility spillovers between studied markets are bidirectional and misspecification of structural breaks made the evaluation of momentum and spillover misleading.

Jahangiri\& Hekmati (2015) studied the relationships between Tehran Stock Exchange, foreign exchange and gold coin markets (as domestic markets) on the one hand, and world oil and gold markets, US stock market and European Stock Market Index (as international markets) on the other hand, and calculated volatility spillover effect during 2001-2013, using Markov Switching Regime. The results reveal that in a low return regime, there are no significant spillover effects between markets. Moreover, when stock markets are in regime zero (low return regime), the gold market acts as an intermediary for the transmission of shocks from global markets to asset markets in Iran. In contrast, when stock markets are in regime one (high return regime), the oil market acts as a transmission channel of shocks to domestic asset markets.

Botshekan et al (2017) address spillovers effects of foreign exchange (dollar and euro) on banks and financial institutes' indexes to explain systemic elements of volatility spillover from exchange market to monetary and financial sectors. To do so, they considered log of return, dynamic conditional correlation and volatility spillover by using four commonly used multivariate GARCH models during 12 years (from the beginning of 2005 until the end of 2016). The results show positive conditional correlations of the dollar in the short-term, volatilities of the euro in the long-term, the existence of spillover effects of exchange rate on banks and financial institutes' index.

Sarrafi et al (2018) examine the symmetric or asymmetric effect of positive and negative shocks of the dollar in the free-market on chemicals and basic metals indices, as two listed industries in the stock exchange with the highest share of non-oil exports in the Iranian economy. They apply weekly data from 2007 to 2016. The results obtained from the primary model, i.e. The Non-Linear Autoregressive Distributive Lag (NARDL) indicate that the effect of increases in dollar rate on both indices in the short and long term is positive 
and significant, and the effect of its decreases is non-significant. Moreover, the derived coefficients imply a higher effect of positive dollar shock in the free market on the chemicals index over the basic metals index. The control variable, i.e. OPEC crude oil price has a direct and significant effect on both indices in the short and long term.

Hatami et al (2018) investigate dynamics of optimal hedge ratio in stock and gold markets. Their results suggest that dynamics of optimal hedge rate have increased during the 2009-2013 period and regime-switching has occurred from 2013 to 2016. Moreover, investors should use gold to hedge their investment in the stock market and consider gold as an item with the stock asset in their portfolio.

Elham Farzanegan (2018) estimates and addresses the performance of hedging performance of cash and future markets of gold coins from 2010-1027 to 2016-7-21, using the new generation of multivariate volatility models. The results reveal the superiority of hedging ratios derived from the GOGARCH model over competitive models, to hedge against volatilities of cash prices with the future price of gold coin. Moreover, cash and future prices tend to co-movement during tensions in the gold coin market.

Nikoumaram et al (2014) investigate exchange and gold markets volatility spillovers on capital market in both EOIs and IOIs during 2007- 2014, using multivariate GARCH model. The results confirm the spillover effect of EOIs from the foreign exchange parallel market; however, the results do not show spillovers from another parallel market, i.e. gold. In this regard, the spillover effect of IOIs from foreign exchange and gold has not been established.

Firouz Fallahi et al (2013) analyze the correlation between volatilities of stock, exchange and gold coin markets in Iran during 2011-2013, using dynamic conditional correlation (DCC-GARCH). The results imply a high conditional correlation between exchange rate return and gold coin, as well as a low conditional correlation between stock index return with exchange and gold coin. Moreover, the equity market is the best place for investment compared to other asset markets.

And finally, Hassan Heidari et al (2012) investigate the relationship between volatilities of real exchange rate and stock price index in Tehran Stock Exchange over the period of 1999 to 2011, using Bivariate Generalized Autoregressive Conditional Heteroskedasticity model (VAR-GARCH). The results suggest that there is a negatively significant relationship between the uncertainty of real exchange rate and stock price index, and no significant relationship is seen between the uncertainty of stock price and exchange rate. 


\section{Research Methodology \\ 1. dynamic correlation model}

Symmetric dynamic conditional correlation (DCC) developed by Engle (2002) and asymmetric dynamic conditional correlation (ADCC) developed by Cappiello et al (2006) to investigate asymmetry of dynamic correlations between financial markets. DCC models involving constant conditional correlation (CCC) developed by Bollerslev (1990) assume that conditional correlations are time-dependent. This model could be estimated even for multidimensional datasets using a two-step procedure. At the first step, conditional variances are derived by estimating a series of univariate GARCH models. In the second step, intercepts of conditional correlations are estimated.

Let $\left\{y_{t}\right\}$ be a $\mathrm{n}^{*} 1$ vector of a multivariate stochastic process and $y_{t}$ be the $\log$ of stock return and log of exchange rate return.

The innovative process of conditional correlation $\varepsilon_{t} \equiv y_{t}-\mu_{t}$, has $\mathrm{n} * \mathrm{n}$ conditional covariance matrix, $\mathrm{H}_{\mathrm{t}}$.

$$
\begin{aligned}
& \mathrm{y}_{\mathrm{t}}=\mu+\varphi \mathrm{y}_{\mathrm{t}-1}+v \varepsilon_{\mathrm{t}-1}+\varepsilon_{\mathrm{t}} \\
& \varepsilon_{\mathrm{t}}=\mathrm{H}_{\mathrm{t}}^{1 / 2} \mathrm{z}_{\mathrm{t}} \\
& \mathrm{z}_{\mathrm{t}} \sim \mathrm{f}\left(\mathrm{z}_{\mathrm{t}}, \mathrm{o}, \mathrm{l}, \mathrm{v}\right) \\
& \mathrm{H}_{\mathrm{t}}=\sigma\left(\mathrm{H}_{\mathrm{t}-1}, \mathrm{H}_{\mathrm{t}-1}, \ldots, \varepsilon_{\mathrm{t}-1}, \varepsilon_{\mathrm{t}-2}, \ldots\right)
\end{aligned}
$$

Where,

$\alpha$ is the vector of constants. $\varphi$ and $v$ refer to an $n \times 1$ vector of co-efficient for AR (1) and MA (1), respectively. $\varepsilon_{t}$ is the vector of residuals. $z_{t}$ is a process with $\mathrm{n}^{*} 1$ vector so that $f\left(z_{t} ; O, I, v\right) . I . E\left(z_{t} z_{t}^{\prime}\right)$ gives multivariate studentdensity function:

$f\left(z_{t} ; o, l, v\right)=\frac{r\left(\frac{v+n}{2}\right)}{r\left(\frac{v}{2}\right)(\pi(v-2))^{n / 2}}\left(1+\frac{z_{t}^{\prime} z_{t}}{v-2}\right)^{\frac{v+2}{2}}$

Where,

$r_{(0)}$ is the gamma function and $\mathrm{v}$ is the degree of freedom for $\mathrm{v}>2$.

The reason for using t-distribution is that it makes modeling with a fat tail possible. Proposed DDC-GARCH by Engle (2002) may successfully be estimated for time-dependent covariance matrices. This covariance matrix of DCC-GARCH could be decomposed as: 
$H_{t}=\sum_{t}^{1 / 2} C_{t} \sum_{t}^{1 / 2}$,

Where,

$\sum_{t}^{1 / 2}$ is a diagonal matrix with conditional standard deviations along the diagonals. It means:

$\sum_{t}^{1 / 2}=\operatorname{diag}\left(\sigma_{1, t}, \sigma_{2, t}, \ldots, \sigma_{n, t}\right)$,

And $c_{t}$ is conditional correlations matrix. Estimation method is composed of two steps. First, conditional variances, $\sigma_{i t}$, for $\mathrm{i}=1, \ldots, \mathrm{n}$ assets are estimated using univariate $\operatorname{GARCH}(1,1)$ proposed by Bollerslev (1986):

$\sigma_{i, t}^{2}=\omega_{i}+a_{i} \varepsilon_{i, t-1}^{2}+b_{i} \sigma_{i, t-1}^{2}$,

In which, parameters $\omega_{i}, \quad a i, b_{i}$ should be estimated.

Second, conditional correlations are estimated using standardized residuals derived in the first step. Specifically, time-varying correlation matrix which is:

$C_{t}=Q_{t}^{*-1 / 2} Q_{t} Q_{t}^{*-1 / 2}$,

And correlation matrix, $Q_{t}=\left(q_{i j, t}\right)$, is calculated as:

$Q_{t}=\left(1-\theta_{1}-\theta_{2}\right) \bar{Q}+\theta_{1}\left(z_{t-1} \dot{z}_{t-1}\right)+\theta_{2} Q_{t-1}$,

In above equation, $z_{t}$ is standardized residuals by conditional standard deviation, i.e. $\left(z_{1, t}, z_{2, t}, \ldots, z_{n, t}\right)^{\prime}=z_{t} ; \quad \bar{Q}=\left(\varepsilon_{1} \sigma_{1, t}^{-1}, \varepsilon_{2} \sigma_{2, t}^{-1}, \ldots, \varepsilon_{n, t} \sigma_{n, t}^{-1}\right)^{\prime}$ is standardized residuals of unconditional covariance, and $Q_{t}^{*-1 / 2}$ is diagonal matrix with reverse toots of arrays in diagonal $Q_{t}$; i.e. $Q_{t}^{*-1 / 2}=\operatorname{diag}\left(q_{1,1, t}^{-1 / 2}, q_{2,2, t}^{-1 / 2}, \ldots, q_{n, n, t}^{-1 / 2}\right)$. Then, correlation coefficients, $\rho_{i j t}$, are given by:

$\rho_{i j, t}=\frac{q_{i j, t}}{\sqrt{q_{i j, t} q_{j j, t}}}, i, j=1,2, \ldots$, nand $i \neq j$,

As asymmetry is not included in Equations 6 and 7, Cappiello et al (2006) extended DCC to build leverage effect on conditional correlation of asset returns and news impact curve. Asymmetric generalized DCC (AG-DCC) is expressed as:

$Q_{t}=\left(\bar{Q}-A^{\prime} \bar{Q} A-B^{\prime} \bar{Q} B-G^{\prime} \bar{N} G\right)+A^{\prime} z_{t-1} z_{t-1}^{\prime}+G^{\prime} n_{t-1} n_{t-1}^{\prime}+B^{\prime} Q_{t-1} B$,

Where, 
The indicator function $\mathrm{n}^{*} 1, n_{t}=I\left[z_{t}<0\right]^{\circ} z_{t}(I[0])$, is equal to 1 when this argument is valid, and 0 otherwise. 'o' indicates Hadamard Product and $Q$ and $\bar{N}$ are unconditional matrices of $z_{t}$ and $n_{t}$. For $\bar{N}=\left[n_{t} n^{\prime}{ }_{t}\right]$, when $Q_{t}$ becomes positive definite with probability 1 that $\left(\bar{Q}-A^{\prime} \bar{Q} A-B^{\prime} \bar{Q} B-G^{\prime} \bar{N} G\right)$ is positive definite. If matrices $A, B, G$ are replaced with scalars $\theta_{1}, \theta_{2}$ and $\theta_{3}$, ADCC $(1,1)$ are distinguished from AG-DCC $(1,1)$. This study focuses only on the asymmetric effect, ignoring the effect of asset-specific news. Therefore, the developed models are used to answer this question that whether conditional correlations between exchange rate return and stock return of EOIs and IOIs tend to change over time, and if is it possible these markets rise during the periods with high volatility due to exchange shocks.

\section{Iterated Cumulative Sum of Squares (ICSS) algorithm}

Structural breaks models have been well documented in macroeconomy and finance. Due to the importance of detecting accurate number and time of structural changes in the variance of financial time-series, numerous methods have been proposed for this purpose. The commonly used method to detect indigenously breakpoints in the variance is Iterated Cumulative Sum of Square (ICSS) algorithm, designed by Inclan and Tiao (1994). ICSS searches for significant changes in variance, created by a structural break in process of generating volatility in time series. This algorithm assumes that the studied time series contain $\mathrm{T}$ observation with normal, uniform and independent distribution (Arago, V, \& Fernandez, M.A, 2007).

It is assumed that the studied time series has constant unconditional variance in the initial period, and suddenly due to an unexpected financial, economic or political event a shock is introduced to the system so that a structural change would occur in the variance of time series. In other words, the occurrence of this shock increases the deviance of current variance from the previous one to the extent that it implicates structural change of market volatility. Then, unconditional variance again turns back to the constant state in a new surface, until in the next shock it would experience another structural change. This process is repeated over time and a time series with $N_{T}$ breakpoints in unconditional variance is generated (Kang, S.H \& Cheong C. \& Yoon, S.M, 2011).

ICSS takes the variance between each pair of breakpoints as fixed and the kurtosis as normal. First, this algorithm is defined for the state that conditional heteroskedasticity exist, while, the empirical evidence shows that most financial and economic time series have often variable variance (or 
heteroskedasticity). Therefore, conventional ICSS is not well enough in case that a dependent process like GARCH exists (Malik, F. \& Ewing, B.T \& Payne, J.E, 2005; Ewing et al, 2013).

Second, ICSS assumes that time series has a normal distribution. However, financial time series often have fat tail distribution with additional kurtosis (>3) (Arago\& Fernandez, 2007). Sanso et al (2003) applied some additional assumptions on $\varepsilon_{t}$ and indicate that for financial data which are not normally distributed and have conditional heteroskedasticity, the validity of IT test results would come into question and if critical values had not been adjusted correctly, erroneous rejection of null hypothesis should be expected. As such, some identified structural breaks in the ICSS algorithm may likely be spurious and the number of real structural breaks invariance would be less than what was detected in conventional ICSS. Thus, they modified Inclan and Tiao (IT) test in order to be applicable when error terms are followed by a dependent process like GARCH (Malik et al, 2005). The number of structural changes resulted from the implementation of Sanso and colleagues' method is remarkably lower than Inclan and Tiao approach (Arago\& Fernandez, 2007).

\section{3. estimation of Optimal portfolio weights (WSE)}

In this section, we examine how weights of the optimal portfolio (WSEs) are extracted between the return of exchange rate and index of EOIs and IOIs during the currency crisis period. The optimal weights of exchange - stock in a one-Rial portfolio for export and import-oriented industries are given as follows:

$W_{s e, t}=\frac{h_{s, t}-h_{s e, t}}{h_{e, t}-2 h_{s e, t}+h_{s, t}}$

$W_{s e, t}=\left\{\begin{array}{ccc}0, & \text { if } & W_{s e, t}<0 \\ W_{s e, t}, & \text { if } & 0 \leq W_{s e, t} \leq 1 \\ 1, & \text { if } & W_{s e, t}>1\end{array}\right.$

Where,

$W_{s e, t}$ is the weight of optimal holding of currencies in a 1Rls portfolio in time

t. $h_{s e, t}$ is conditional covariance between the stock price index and exchange price, $h_{s, t}$ is the conditional variance of stock price index, and $h_{e, t}$ is the conditional variance of exchange price in time $t$. 


\section{Research Findings}

\section{Data}

In this study, the weekly data of the unofficial exchange rate and the daily price index of EOIs and IOIs from December 2008 to September 2020 were used. The logarithmic difference of consecutive prices of stock index and the exchange rate is used to calculate price return. The natural log of net price return is defined as follow:

$r_{t}=\ln \left(P_{t}\right)-\ln \left(P_{t-1}\right)=\ln \frac{P_{t}}{P_{t-1}}$

Tehran Stock Exchange data were extracted from tse.ir. Daily dollar price in the free market is not announced by any official reference and the author gathered these data by using the published data on the website of reliable Tehran currency exchanges. In the process of research, Augmented DickeyFuller (ADF) and Breakpoint ADF tests were used to evaluate the stationarity of variables. The results of these tests show that all variables are stationary at the level of $99 \%$.

Table 1. Results of Unit Root test

\begin{tabular}{|l|l|l|}
\hline & ADF & Breakpoint ADF \\
\hline Exchange rate & $-52.80^{* * * *}$ & $-54.37^{* * *}$ \\
\hline Car & $-23.61^{* * * *}$ & $-38.38^{* * *}$ \\
\hline Computer & $-37.31^{* * * *}$ & $-38.72^{* * *}$ \\
\hline Cement & $-14.93^{* * * *}$ & $-32.15^{* * *}$ \\
\hline Chemicals & $-23.56^{* * * *}$ & $-36.41^{* * *}$ \\
\hline Petroleum & $-24.40^{* * * *}$ & $-40.51^{* * *}$ \\
\hline Basic metals & $-23.28^{* * * *}$ & $-38.07^{* * * *}$ \\
\hline Tile and ceramics & $-22.94^{* * * *}$ & $-36.32^{* * *}$ \\
\hline Metal ores & $-24.22^{* * *}$ & $-38.75^{* * *}$ \\
\hline Pharmaceutical & $-21.76^{* * *}$ & $-30.12^{* * *}$ \\
\hline
\end{tabular}

Source: research findings

As two currency crises occurred in Iran during the studied period, then in each crisis, hedging models were estimated independently. Several econometrics methods can be used to detect structural breakpoints, and subsequently the critical points. In this study, as the exchange time series has a fat tail and conditional heteroskedasticity, the modified iterated cumulative sum of squares algorithm, presented in Section 3.2, has been used and the results are reported in Table 2. 
Iranian Journal of Finance, 2021, Vol. 5, No. 4 (Bazraei, M.)

Table 2. Results of structural break test for the currency

\begin{tabular}{|l|l|l|l|l|l|}
\hline \multicolumn{2}{|c|}{ ICSS (IT) } & \multicolumn{2}{c|}{ ICSS $\left(\kappa_{1}\right)$} & \multicolumn{2}{c|}{ ICSS $\left(\kappa_{2}\right)^{4}$} \\
\hline $1388 / 04 / 03$ & $(130)$ & $1390 / 09 / 05$ & $(720)$ & $1390 / 09 / 05$ & $(720)$ \\
\hline $1389 / 07 / 17$ & $(444)$ & $1392 / 04 / 04$ & $(1096$ & $1397 / 01 / 15$ & $(2252)$ \\
\hline & & $1392 / 07 / 08$ & $(1162)$ & $1397 / 10 / 09$ & $(2432)$ \\
\hline & & $1392 / 12 / 07$ & $(1263)$ & & \\
\hline & & $1393 / 02 / 28$ & $(1314)$ & & \\
\hline & & $1393 / 09 / 04$ & $(1442)$ & & \\
\hline & & $1393 / 09 / 25$ & $(1456)$ & & \\
\hline & & $1396 / 10 / 06$ & $(2190)$ & & \\
\hline & & $1397 / 01 / 18$ & $(2253)$ & & \\
\hline
\end{tabular}

Source: research findings

Structural break tests estimate the peak of crisis; in fact, they detect the point in which the highest changes occurred in the exchange rate. Results of the ICSS test detected two breakpoints in the exchange rate, contemporaneous to two foreign exchange shocks that occurred during the 2010s in Iran. According to the results of the modified ICSS, the starting point of the first and second exchange crises was assumed November 26, 2011, and April 4, 2017, respectively.

Table 3. Summary of descriptive statistics

\begin{tabular}{|c|c|c|c|c|c|c|c|c|c|c|c|}
\hline & 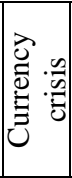 & 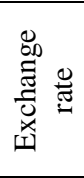 & U্ঠ & 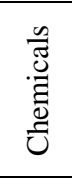 & $\begin{array}{l}\Xi \\
\frac{\Xi}{0} \\
0 \\
0 \\
0\end{array}$ & 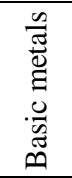 & 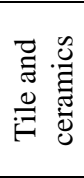 & $\frac{\tilde{d}}{0}$ & Uี & 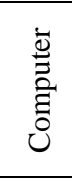 & 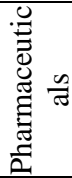 \\
\hline \multirow{2}{*}{ Mean } & 1 & 0.09 & 0.12 & 0.22 & 0.24 & 0.19 & 0.17 & 0.19 & 0.11 & 0.22 & 0.16 \\
\hline & 2 & 0.12 & 0.17 & 0.18 & 0.19 & 0.20 & 0.19 & 0.18 & 0.22 & 0.19 & 0.22 \\
\hline \multirow{2}{*}{ Maximum } & 1 & $\begin{array}{c}22.8 \\
8\end{array}$ & $\begin{array}{c}10.7 \\
9\end{array}$ & 8.98 & 25.66 & 8.54 & 9.75 & 9.69 & 8.02 & $\begin{array}{c}18.9 \\
8\end{array}$ & 6.27 \\
\hline & 2 & $\begin{array}{c}18.3 \\
8 \\
\end{array}$ & 5.35 & 4.94 & 6.59 & 6.48 & $\begin{array}{c}13.3 \\
1 \\
\end{array}$ & 9.13 & $\begin{array}{c}13.5 \\
1 \\
\end{array}$ & 9.78 & 5.76 \\
\hline \multirow{2}{*}{ Minimum } & 1 & $\begin{array}{c}- \\
11.5 \\
2\end{array}$ & $\begin{array}{c}- \\
2.99\end{array}$ & $\begin{array}{c}- \\
6.76\end{array}$ & $\begin{array}{c}- \\
10.19\end{array}$ & $\begin{array}{c}- \\
4.76\end{array}$ & $\begin{array}{c}- \\
15.5 \\
0\end{array}$ & $\begin{array}{c}- \\
17.0 \\
1\end{array}$ & $\begin{array}{c}- \\
7.55\end{array}$ & $\begin{array}{c}- \\
3.98\end{array}$ & $\begin{array}{c}- \\
1.87\end{array}$ \\
\hline & 2 & $\begin{array}{c}- \\
20.9 \\
8\end{array}$ & 4.00 & $\begin{array}{c}- \\
5.84\end{array}$ & -8.56 & $\begin{array}{c}- \\
8.14\end{array}$ & $\begin{array}{c}- \\
6.64\end{array}$ & $\begin{array}{c}- \\
4.90\end{array}$ & - & $\begin{array}{c}- \\
4.93\end{array}$ & $\overline{-} .35$ \\
\hline
\end{tabular}

${ }^{4}$ The reader is referred to Sanso et al (2003) to get more information. 
Dynamic correlation between exchange rate and the listed...

\begin{tabular}{|c|c|c|c|c|c|c|c|c|c|c|c|}
\hline \multirow{2}{*}{ S. E } & 1 & 1.82 & 0.81 & 1.07 & 1.77 & 1.22 & 1.19 & 1.54 & 1.45 & 1.52 & 0.59 \\
\hline & 2 & 1.81 & 1.29 & 1.30 & 1.81 & 1.49 & 1.52 & 1.65 & 2.17 & 1.29 & 1.22 \\
\hline \multirow[t]{2}{*}{ Skewness } & 1 & 2.11 & 3.35 & 0.64 & 4.67 & 0.56 & $\begin{array}{c}- \\
0.70\end{array}$ & $\overline{-}$ & 0.53 & 3.41 & 3.25 \\
\hline & 2 & 0.34 & 0.61 & 0.40 & 0.10 & 0.43 & 1.06 & 0.80 & 0.38 & 0.60 & 0.65 \\
\hline \multirow{2}{*}{ Kurtosis } & 1 & $\begin{array}{c}37.5 \\
8\end{array}$ & $\begin{array}{c}34.3 \\
5\end{array}$ & $\begin{array}{c}12.1 \\
2\end{array}$ & 65.19 & 6.45 & $\begin{array}{c}35.1 \\
5\end{array}$ & $\begin{array}{c}19.1 \\
0\end{array}$ & 5.25 & $\begin{array}{c}38.8 \\
1\end{array}$ & $\begin{array}{c}23.5 \\
9\end{array}$ \\
\hline & 2 & $\begin{array}{c}34.7 \\
4\end{array}$ & 4.17 & 6.29 & 4.18 & 5.55 & 9.52 & 5.57 & 4.29 & 8.16 & 6.02 \\
\hline \multirow{2}{*}{$\begin{array}{c}\text { JarqueBera test } \\
\text { statistic }\end{array}$} & 1 & $\begin{array}{c}5864 \\
0 \\
(0.0 \\
0) \\
\end{array}$ & $\begin{array}{c}4966 \\
7 \\
(0.0 \\
0) \\
\end{array}$ & $\begin{array}{c}4101 \\
(0.0 \\
0)\end{array}$ & $\begin{array}{c}1911 \\
70 \\
(0.00 \\
)\end{array}$ & $\begin{array}{c}636 \\
(0.0 \\
0)\end{array}$ & $\begin{array}{c}5006 \\
9 \\
(0.0 \\
0) \\
\end{array}$ & $\begin{array}{c}1255 \\
9 \\
(0.0 \\
0)\end{array}$ & $\begin{array}{c}298 \\
(0.0 \\
0)\end{array}$ & $\begin{array}{c}6424 \\
0 \\
(0.0 \\
0) \\
\end{array}$ & $\begin{array}{c}2254 \\
2 \\
(0.0 \\
0) \\
\end{array}$ \\
\hline & 2 & $\begin{array}{c}7009 \\
1 \\
(0.0 \\
0)\end{array}$ & $\begin{array}{c}198 \\
(0.0 \\
0)\end{array}$ & $\begin{array}{c}796 \\
(0.0 \\
0)\end{array}$ & $\begin{array}{c}100 \\
(0.00 \\
)\end{array}$ & $\begin{array}{c}506 \\
(0.0 \\
0)\end{array}$ & $\begin{array}{c}3272 \\
(0.0 \\
0)\end{array}$ & $\begin{array}{c}640 \\
(0.0 \\
0)\end{array}$ & $\begin{array}{c}156 \\
(0.0 \\
0)\end{array}$ & $\begin{array}{c}1947 \\
(0.0 \\
0)\end{array}$ & $\begin{array}{c}755 \\
(0.0 \\
0)\end{array}$ \\
\hline \multirow{2}{*}{$\begin{array}{l}\text { LM-ARCH test } \\
\text { statistics }\end{array}$} & 1 & $\begin{array}{c}14.8 \\
(0.0 \\
0)\end{array}$ & $\begin{array}{c}11.8 \\
(0.0 \\
0)\end{array}$ & $\begin{array}{c}8.3 \\
(0.0 \\
0)\end{array}$ & $\begin{array}{c}0.02 \\
(0.98 \\
)\end{array}$ & $\begin{array}{c}5.2 \\
(0.0 \\
0)\end{array}$ & $\begin{array}{c}0.00 \\
1 \\
(0.9 \\
9)\end{array}$ & $\begin{array}{c}4.6 \\
(0.0 \\
0)\end{array}$ & $\begin{array}{c}34.0 \\
(0.0 \\
0)\end{array}$ & $\begin{array}{c}11.9 \\
(0.0 \\
0)\end{array}$ & $\begin{array}{c}84.7 \\
(0.0 \\
0)\end{array}$ \\
\hline & 2 & $\begin{array}{c}50.3 \\
(0.0 \\
0)\end{array}$ & $\begin{array}{c}289 . \\
6 \\
(0.0 \\
0) \\
\end{array}$ & $\begin{array}{c}304 . \\
0 \\
(0.0 \\
0) \\
\end{array}$ & $\begin{array}{c}161.8 \\
(0.00 \\
)\end{array}$ & $\begin{array}{c}132 . \\
3 \\
(0.0 \\
0) \\
\end{array}$ & $\begin{array}{c}38.6 \\
(0.0 \\
0)\end{array}$ & $\begin{array}{c}144 . \\
3 \\
(0.0 \\
0)\end{array}$ & $\begin{array}{c}17.3 \\
(0.0 \\
0)\end{array}$ & $\begin{array}{c}111 . \\
5 \\
(0.0 \\
0) \\
\end{array}$ & $\begin{array}{c}387 . \\
5 \\
(0.0 \\
0) \\
\end{array}$ \\
\hline \multirow{2}{*}{$\begin{array}{l}\text { Spearman } \\
\text { Correlation }\end{array}$} & 1 & $\begin{array}{c}100 \\
\%\end{array}$ & $\begin{array}{c}- \\
0 / 01 \\
2\end{array}$ & $\begin{array}{c}- \\
0 / 05 \\
9\end{array}$ & $\begin{array}{l}- \\
0 / 025\end{array}$ & $\begin{array}{c}- \\
0 / 04\end{array}$ & $\begin{array}{c}0 / 01 \\
2\end{array}$ & $\begin{array}{c}- \\
0 / 03 \\
5\end{array}$ & $\begin{array}{c}0 / 00 \\
9\end{array}$ & $\begin{array}{c}- \\
0 / 00 \\
7\end{array}$ & $\begin{array}{c}- \\
0 / 02 \\
6\end{array}$ \\
\hline & 2 & $\begin{array}{c}100 \\
\%\end{array}$ & $\begin{array}{c}0 / 00 \\
0\end{array}$ & $\begin{array}{c}- \\
0 / 00 \\
5\end{array}$ & $0 / 04$ & $\begin{array}{c}0 / 00 \\
4\end{array}$ & $\begin{array}{c}0 / 01 \\
6\end{array}$ & $\begin{array}{c}- \\
0 / 01 \\
5\end{array}$ & $\begin{array}{c}0 / 01 \\
9\end{array}$ & $0 / 04$ & $\begin{array}{c}0 / 02 \\
6\end{array}$ \\
\hline \multirow{2}{*}{$\begin{array}{l}\text { Pearson } \\
\text { Correlation }\end{array}$} & 1 & $\begin{array}{c}100 \\
\%\end{array}$ & $\begin{array}{c}0.00 \\
0\end{array}$ & $\begin{array}{c}- \\
0.04 \\
6\end{array}$ & 0.005 & $\begin{array}{c}- \\
0.03 \\
1\end{array}$ & $\begin{array}{c}0.00 \\
5\end{array}$ & $\begin{array}{c}- \\
0.02 \\
6\end{array}$ & $\begin{array}{c}- \\
0.04 \\
4\end{array}$ & $\begin{array}{c}- \\
0.03 \\
2\end{array}$ & $\begin{array}{c}- \\
0.02 \\
2\end{array}$ \\
\hline & 2 & $\begin{array}{c}100 \\
\%\end{array}$ & $\begin{array}{c}0.03 \\
5\end{array}$ & $\begin{array}{c}0.01 \\
7\end{array}$ & 0.042 & $\begin{array}{c}0.03 \\
3\end{array}$ & $\begin{array}{c}0.01 \\
5\end{array}$ & $\begin{array}{c}0.02 \\
0\end{array}$ & $\begin{array}{c}0.05 \\
9\end{array}$ & $\begin{array}{c}0.04 \\
7\end{array}$ & $\begin{array}{c}0.02 \\
8\end{array}$ \\
\hline \multirow{2}{*}{$\begin{array}{l}\text { Kendall's } \\
\text { Correlation }\end{array}$} & 1 & $\begin{array}{c}100 \\
\%\end{array}$ & $\begin{array}{c}0.00 \\
8 \\
\end{array}$ & $\begin{array}{c}0.04 \\
1 \\
\end{array}$ & $0 . \overline{-}$ & $\begin{array}{c}0.02 \\
8 \\
\end{array}$ & $\begin{array}{c}0.00 \\
9\end{array}$ & $\begin{array}{c}0.02 \\
4 \\
\end{array}$ & $\begin{array}{c}- \\
0.00 \\
5 \\
\end{array}$ & $\begin{array}{c}- \\
0.00 \\
5 \\
\end{array}$ & $\begin{array}{c}0.01 \\
7 \\
\end{array}$ \\
\hline & 2 & $\begin{array}{c}100 \\
\%\end{array}$ & $\begin{array}{c}- \\
0.00 \\
3\end{array}$ & $\begin{array}{c}- \\
0.00 \\
5\end{array}$ & 0.027 & $\begin{array}{c}0.00 \\
2\end{array}$ & $\begin{array}{c}0.01 \\
3\end{array}$ & $\begin{array}{c}- \\
0.01 \\
1\end{array}$ & $\begin{array}{c}0.01 \\
3\end{array}$ & $\begin{array}{c}0.02 \\
8\end{array}$ & $\begin{array}{c}0.01 \\
7\end{array}$ \\
\hline
\end{tabular}

Source: research findings

Table 3 summarizes descriptive statistics of return series of EOIs and IOIs with exchange rates during the first and second exchange crises. For all indices, the standard deviation is bigger than the mean. The means are positive for all assets; such that in the first exchange crisis, the minimum and maximum value of mean belongs to automobile and oil products industries. Moreover, the 
highest standard deviation is seen in oil products and the lowest one in the pharmaceutical industry. In the second exchange crisis, the lowest mean belongs to cement and the highest value to automobile, pharmaceuticals and multidisciplinary industries. Considering the LM-ARCH test, in the first crisis, the existence of heteroskedasticity is not rejected for all industries except oil products and tile and ceramics. However, in the second crisis, this possibility is not rejected for all industries. As the kurtosis ratio of returns is higher than the kurtosis of the normal density function, then, the density function of these assets in both crises are fat-tailed with a high peak. Jarqu-Bera test statistics suggest that distribution functions of the studied returns in both crises would not be normal.

\section{Empirical Results}

In this study, the time-varying asymmetric dynamic correlation pattern was estimated for two groups of industries, i.e. export-oriented and import oriented, and if variables didn't follow the pattern, the symmetric dynamic correlation model would be estimated. Given the non-normality of returns, DCC and $\mathrm{ADCC}^{5}$ models are estimated with multivariate t-distribution. In tables 4 and 5, the results of symmetric DCC and asymmetric ADCC between stock returns of EOIs and IOIs with exchange rates are reported. The reason for this categorization goes back to the fact that whether different categories respond differently to the exchange shocks.

Table 4. Results of DCC and ADCC parameters in IOIs

\begin{tabular}{|c|c|c|c|c|c|c|c|c|c|c|c|c|c|}
\hline & & \multicolumn{3}{|c|}{$\mathrm{ADCC}_{-}$First crisis } & \multicolumn{3}{|c|}{$\mathrm{DCC}_{-}$First crisis } & \multicolumn{3}{|c|}{$\begin{array}{c}\mathrm{ADCC}_{-} \text {Second } \\
\text { crisis }\end{array}$} & \multicolumn{3}{|c|}{$\begin{array}{c}\mathrm{DCC}_{-} \text {Second } \\
\text { crisis }\end{array}$} \\
\hline & & $\begin{array}{c}\text { Coef } \\
.\end{array}$ & $\mathrm{t}$ & prob & $\begin{array}{l}\text { Coe } \\
\text { f. }\end{array}$ & $\mathrm{t}$ & prob & $\begin{array}{l}\text { Coe } \\
\text { f. }\end{array}$ & $\mathrm{t}$ & prob & $\begin{array}{c}\text { Coe } \\
\text { f. }\end{array}$ & $\mathrm{t}$ & $\begin{array}{c}\text { pro } \\
\text { b }\end{array}$ \\
\hline \multirow{6}{*}{ 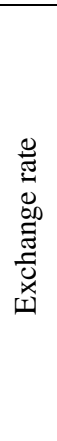 } & $\mu$ & $\begin{array}{c}0.01 \\
2\end{array}$ & $\begin{array}{c}1.90 \\
0 \\
\end{array}$ & 0.056 & $\begin{array}{l}0.0 \\
11 \\
\end{array}$ & $\begin{array}{c}1.64 \\
0 \\
\end{array}$ & 0.100 & $\begin{array}{l}0.0 \\
04\end{array}$ & $\begin{array}{c}0.55 \\
6 \\
\end{array}$ & 0.577 & $\begin{array}{c}0.0 \\
03 \\
\end{array}$ & $\begin{array}{c}0.43 \\
0 \\
\end{array}$ & $\begin{array}{l}0.6 \\
60 \\
\end{array}$ \\
\hline & $\varphi$ & $\begin{array}{c}0.89 \\
1\end{array}$ & $\begin{array}{c}- \\
14.2 \\
30\end{array}$ & 0.000 & $\begin{array}{l}0.8 \\
93\end{array}$ & $\begin{array}{c}11.9 \\
70\end{array}$ & 0.000 & $\begin{array}{l}0.6 \\
00\end{array}$ & $\begin{array}{c}10.8 \\
00\end{array}$ & 0.000 & $\begin{array}{c}- \\
0.6 \\
02\end{array}$ & $\begin{array}{c}- \\
11.5 \\
40\end{array}$ & $\begin{array}{l}0.0 \\
00\end{array}$ \\
\hline & $v$ & $\begin{array}{c}0.87 \\
6\end{array}$ & $\begin{array}{c}13.6 \\
70\end{array}$ & 0.000 & $\begin{array}{l}0.8 \\
77\end{array}$ & $\begin{array}{c}11.3 \\
30\end{array}$ & 0.000 & $\begin{array}{l}0.5 \\
96\end{array}$ & $\begin{array}{c}10.6 \\
00\end{array}$ & 0.000 & $\begin{array}{l}0.5 \\
99\end{array}$ & $\begin{array}{c}10.7 \\
30\end{array}$ & $\begin{array}{l}0.0 \\
00\end{array}$ \\
\hline & $\omega$ & $\begin{array}{c}0.00 \\
5\end{array}$ & $\begin{array}{c}1.75 \\
0\end{array}$ & 0.081 & $\begin{array}{l}0.0 \\
04\end{array}$ & $\begin{array}{c}1.82 \\
0\end{array}$ & 0.069 & $\begin{array}{c}0.0 \\
03\end{array}$ & $\begin{array}{c}1.18 \\
0\end{array}$ & 0.239 & $\begin{array}{c}0.0 \\
03\end{array}$ & $\begin{array}{c}1.20 \\
0\end{array}$ & $\begin{array}{l}0.2 \\
31\end{array}$ \\
\hline & $\alpha$ & $\begin{array}{c}0.15 \\
7\end{array}$ & $\begin{array}{c}2.19 \\
0\end{array}$ & 0.029 & $\begin{array}{l}0.1 \\
35\end{array}$ & $\begin{array}{c}2.77 \\
0\end{array}$ & 0.006 & $\begin{array}{c}0.1 \\
03\end{array}$ & $\begin{array}{c}4.07 \\
0\end{array}$ & 0.000 & $\begin{array}{c}0.1 \\
99\end{array}$ & $\begin{array}{c}4.29 \\
0\end{array}$ & $\begin{array}{l}0.0 \\
00\end{array}$ \\
\hline & $\beta$ & 0.80 & 21.7 & 0.000 & 0.8 & 23.3 & 0.000 & 0.7 & 14.9 & 0.000 & 0.7 & 15.7 & 0.0 \\
\hline
\end{tabular}

\footnotetext{
5 .To estimate these models, the G@GARCH Package of OxMetric8.02 software is used.
} 
Dynamic correlation between exchange rate and the listed...

\begin{tabular}{|c|c|c|c|c|c|c|c|c|c|c|c|c|c|}
\hline & & 5 & 40 & & 09 & 20 & & 39 & 50 & & 31 & 00 & 00 \\
\hline & $\gamma$ & $\begin{array}{c}- \\
0.02 \\
1 \\
\end{array}$ & $\begin{array}{c}- \\
0.13 \\
0 \\
\end{array}$ & 0.897 & & & & $\begin{array}{c}- \\
0.0 \\
68 \\
\end{array}$ & $\begin{array}{c}1.03 \\
0 \\
\end{array}$ & 0.302 & & & \\
\hline \multirow{7}{*}{ Uี } & $\mu$ & $\begin{array}{c}0.02 \\
0\end{array}$ & $\begin{array}{c}1.59 \\
0\end{array}$ & 0.110 & $\begin{array}{c}0.0 \\
15\end{array}$ & $\begin{array}{c}0.92 \\
1\end{array}$ & 0.357 & $\begin{array}{c}0.0 \\
43\end{array}$ & $\begin{array}{c}0.83 \\
3\end{array}$ & 0.400 & $\begin{array}{c}0.0 \\
24\end{array}$ & $\begin{array}{c}0.48 \\
6\end{array}$ & $\begin{array}{c}0.6 \\
26\end{array}$ \\
\hline & $\varphi$ & $\begin{array}{c}0.18 \\
0\end{array}$ & $\begin{array}{c}2.18 \\
0\end{array}$ & 0.029 & $\begin{array}{c}0.1 \\
80\end{array}$ & $\begin{array}{c}2.34 \\
8\end{array}$ & 0.019 & $\begin{array}{c}- \\
0.3 \\
13\end{array}$ & $\begin{array}{c}- \\
2.22 \\
0\end{array}$ & 0.026 & $\begin{array}{c}- \\
0.3 \\
12\end{array}$ & $\begin{array}{c}- \\
2.27 \\
8\end{array}$ & $\begin{array}{l}0.0 \\
23\end{array}$ \\
\hline & $v$ & $\begin{array}{c}0.20 \\
0\end{array}$ & $\begin{array}{c}2.68 \\
0\end{array}$ & 0.007 & $\begin{array}{c}0.2 \\
11\end{array}$ & $\begin{array}{c}3.08 \\
4\end{array}$ & 0.002 & $\begin{array}{c}0.5 \\
58\end{array}$ & $\begin{array}{c}4.33 \\
0\end{array}$ & 0.000 & $\begin{array}{c}0.5 \\
56\end{array}$ & $\begin{array}{c}4.45 \\
0\end{array}$ & $\begin{array}{c}0.0 \\
00\end{array}$ \\
\hline & $\omega$ & $\begin{array}{c}0.00 \\
1\end{array}$ & $\begin{array}{c}0.62 \\
0\end{array}$ & 0.534 & $\begin{array}{c}0.0 \\
01\end{array}$ & $\begin{array}{c}0.67 \\
0\end{array}$ & 0.505 & $\begin{array}{c}0.0 \\
61\end{array}$ & $\begin{array}{c}1.18 \\
0\end{array}$ & 0.240 & $\begin{array}{l}0.0 \\
52\end{array}$ & $\begin{array}{c}1.08 \\
0\end{array}$ & $\begin{array}{c}0.2 \\
81\end{array}$ \\
\hline & $\alpha$ & $\begin{array}{c}0.10 \\
8\end{array}$ & $\begin{array}{c}3.06 \\
0\end{array}$ & 0.002 & $\begin{array}{c}0.1 \\
16\end{array}$ & $\begin{array}{c}3.09 \\
0\end{array}$ & 0.002 & $\begin{array}{c}0.1 \\
14\end{array}$ & $\begin{array}{c}4.49 \\
0\end{array}$ & 0.000 & $\begin{array}{c}0.1 \\
05\end{array}$ & $\begin{array}{c}4.82 \\
0\end{array}$ & $\begin{array}{c}0.0 \\
00\end{array}$ \\
\hline & $\beta$ & $\begin{array}{c}0.87 \\
4\end{array}$ & $\begin{array}{c}25.1 \\
20\end{array}$ & 0.000 & $\begin{array}{c}0.8 \\
67\end{array}$ & $\begin{array}{c}25.0 \\
50\end{array}$ & 0.000 & $\begin{array}{c}0.7 \\
12\end{array}$ & $\begin{array}{c}14.5 \\
30\end{array}$ & 0.000 & $\begin{array}{c}0.8 \\
16\end{array}$ & $\begin{array}{c}48.7 \\
00\end{array}$ & $\begin{array}{l}0.0 \\
00\end{array}$ \\
\hline & $\gamma$ & $\begin{array}{c}- \\
0.11 \\
5\end{array}$ & $\begin{array}{c}- \\
0.97 \\
0\end{array}$ & 0.332 & & & & $\begin{array}{c}- \\
0.0 \\
29\end{array}$ & $\begin{array}{c}- \\
1.22 \\
0\end{array}$ & 0.221 & & & \\
\hline \multirow{7}{*}{ 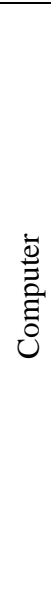 } & $\mu$ & $\begin{array}{c}0.01 \\
3\end{array}$ & $\begin{array}{c}1.32 \\
0\end{array}$ & 0.185 & $\begin{array}{c}0.0 \\
13\end{array}$ & $\begin{array}{c}1.29 \\
0\end{array}$ & 0.196 & $\begin{array}{l}0.0 \\
36\end{array}$ & $\begin{array}{c}2.06 \\
7\end{array}$ & 0.039 & $\begin{array}{c}0.0 \\
17\end{array}$ & $\begin{array}{c}1.05 \\
5\end{array}$ & $\begin{array}{c}0.2 \\
90\end{array}$ \\
\hline & $\varphi$ & $\begin{array}{c}0.62 \\
3\end{array}$ & $\begin{array}{c}6.85 \\
0\end{array}$ & 0.000 & $\begin{array}{l}0.5 \\
95\end{array}$ & $\begin{array}{c}6.43 \\
0\end{array}$ & 0.000 & $\begin{array}{c}0.3 \\
30\end{array}$ & $\begin{array}{c}4.14 \\
0\end{array}$ & 0.000 & $\begin{array}{c}0.3 \\
38\end{array}$ & $\begin{array}{c}4.31 \\
1\end{array}$ & $\begin{array}{c}0.0 \\
00\end{array}$ \\
\hline & $v$ & $\begin{array}{c}- \\
0.31 \\
6\end{array}$ & $\begin{array}{c}- \\
2.76 \\
5\end{array}$ & 0.005 & $\begin{array}{c}- \\
0.2 \\
83\end{array}$ & $\begin{array}{c}- \\
2.52 \\
0\end{array}$ & 0.012 & $\begin{array}{l}0.0 \\
37\end{array}$ & $\begin{array}{c}0.41 \\
8\end{array}$ & 0.675 & $\begin{array}{l}0.0 \\
25\end{array}$ & $\begin{array}{c}0.30 \\
9\end{array}$ & $\begin{array}{l}0.7 \\
57\end{array}$ \\
\hline & $\omega$ & $\begin{array}{c}0.00 \\
1\end{array}$ & $\begin{array}{c}0.70 \\
0\end{array}$ & 0.485 & $\begin{array}{c}0.0 \\
01\end{array}$ & $\begin{array}{c}0.93 \\
0\end{array}$ & 0.354 & $\begin{array}{l}0.0 \\
26\end{array}$ & $\begin{array}{c}3.70 \\
0\end{array}$ & 0.000 & $\begin{array}{l}0.0 \\
26\end{array}$ & $\begin{array}{c}3.24 \\
0\end{array}$ & $\begin{array}{c}0.0 \\
01\end{array}$ \\
\hline & $\alpha$ & $\begin{array}{c}0.16 \\
6\end{array}$ & $\begin{array}{c}2.10 \\
0\end{array}$ & 0.036 & $\begin{array}{c}0.1 \\
12\end{array}$ & $\begin{array}{c}2.28 \\
0\end{array}$ & 0.023 & $\begin{array}{c}0.1 \\
79\end{array}$ & $\begin{array}{c}5.46 \\
0\end{array}$ & 0.000 & $\begin{array}{l}0.2 \\
84\end{array}$ & $\begin{array}{c}4.84 \\
0\end{array}$ & $\begin{array}{l}0.0 \\
00\end{array}$ \\
\hline & $\beta$ & $\begin{array}{c}0.82 \\
5\end{array}$ & $\begin{array}{c}19.1 \\
00\end{array}$ & 0.000 & $\begin{array}{c}0.8 \\
30\end{array}$ & $\begin{array}{c}19.0 \\
80\end{array}$ & 0.000 & $\begin{array}{c}0.7 \\
05\end{array}$ & $\begin{array}{c}16.4 \\
10\end{array}$ & 0.000 & $\begin{array}{l}0.6 \\
87\end{array}$ & $\begin{array}{c}13.5 \\
80\end{array}$ & $\begin{array}{c}0.0 \\
00\end{array}$ \\
\hline & $\gamma$ & $\begin{array}{c}- \\
0.30 \\
7\end{array}$ & $\begin{array}{c}- \\
1.51 \\
0\end{array}$ & 0.130 & & & & $\begin{array}{c}- \\
0.2 \\
94\end{array}$ & $\begin{array}{c}- \\
4.16 \\
0\end{array}$ & 0.000 & & & \\
\hline \multirow{7}{*}{ 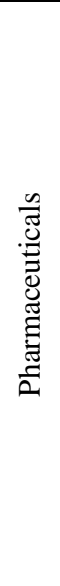 } & $\mu$ & $\begin{array}{c}0.03 \\
8\end{array}$ & $\begin{array}{c}2.19 \\
0\end{array}$ & 0.028 & $\begin{array}{l}0.0 \\
22\end{array}$ & $\begin{array}{c}1.30 \\
0\end{array}$ & 0.194 & $\begin{array}{c}0.0 \\
08\end{array}$ & $\begin{array}{c}0.50 \\
4\end{array}$ & 0.610 & $\begin{array}{l}0.0 \\
01\end{array}$ & $\begin{array}{c}0.03 \\
9\end{array}$ & $\begin{array}{c}0.9 \\
70\end{array}$ \\
\hline & $\varphi$ & $\begin{array}{c}0.75 \\
0\end{array}$ & $\begin{array}{c}14.4 \\
10\end{array}$ & 0.000 & $\begin{array}{r}0.7 \\
60\end{array}$ & $\begin{array}{c}11.3 \\
00\end{array}$ & 0.000 & $\begin{array}{c}0.4 \\
99\end{array}$ & $\begin{array}{c}8.28 \\
0\end{array}$ & 0.000 & $\begin{array}{c}0.4 \\
86\end{array}$ & $\begin{array}{c}8.23 \\
8\end{array}$ & $\begin{array}{c}0.0 \\
00\end{array}$ \\
\hline & $v$ & $\begin{array}{c}- \\
0.41 \\
6 \\
\end{array}$ & $\begin{array}{c}- \\
4.96 \\
4 \\
\end{array}$ & 0.000 & $\begin{array}{c}- \\
0.4 \\
25 \\
\end{array}$ & $\begin{array}{c}- \\
3.95 \\
0 \\
\end{array}$ & 0.000 & $\begin{array}{c}- \\
0.0 \\
58\end{array}$ & $\begin{array}{c}- \\
0.78 \\
6 \\
\end{array}$ & 0.432 & $\begin{array}{c}- \\
0.0 \\
46 \\
\end{array}$ & $\begin{array}{c}- \\
0.64 \\
9 \\
\end{array}$ & $\begin{array}{l}0.5 \\
16\end{array}$ \\
\hline & $\omega$ & $\begin{array}{c}0.02 \\
0\end{array}$ & $\begin{array}{c}1.41 \\
0\end{array}$ & 0.158 & $\begin{array}{l}0.0 \\
27\end{array}$ & $\begin{array}{c}1.65 \\
0\end{array}$ & 0.099 & $\begin{array}{c}0.0 \\
04\end{array}$ & $\begin{array}{c}2.22 \\
0\end{array}$ & 0.027 & $\begin{array}{c}0.0 \\
03\end{array}$ & $\begin{array}{c}1.99 \\
0\end{array}$ & $\begin{array}{l}0.0 \\
47\end{array}$ \\
\hline & $\alpha$ & $\begin{array}{c}0.19 \\
6\end{array}$ & $\begin{array}{c}1.51 \\
0\end{array}$ & 0.133 & $\begin{array}{c}0.3 \\
06\end{array}$ & $\begin{array}{c}2.04 \\
0\end{array}$ & 0.042 & $\begin{array}{l}0.1 \\
24\end{array}$ & $\begin{array}{c}3.60 \\
0\end{array}$ & 0.000 & $\begin{array}{c}0.1 \\
30\end{array}$ & $\begin{array}{c}3.79 \\
0\end{array}$ & $\begin{array}{c}0.0 \\
00\end{array}$ \\
\hline & $\beta$ & $\begin{array}{c}0.75 \\
6\end{array}$ & $\begin{array}{c}5.11 \\
0\end{array}$ & 0.000 & $\begin{array}{c}0.6 \\
48\end{array}$ & $\begin{array}{c}5.16 \\
0\end{array}$ & 0.000 & $\begin{array}{c}0.8 \\
60\end{array}$ & $\begin{array}{c}25.5 \\
70\end{array}$ & 0.000 & $\begin{array}{c}0.8 \\
61 \\
\end{array}$ & $\begin{array}{c}25.4 \\
20 \\
\end{array}$ & $\begin{array}{c}0.0 \\
00 \\
\end{array}$ \\
\hline & $\gamma$ & $\begin{array}{c}- \\
0.60 \\
8\end{array}$ & $\begin{array}{c}- \\
1.84 \\
0\end{array}$ & 0.067 & & & & $\begin{array}{c}- \\
0.1 \\
14\end{array}$ & $\begin{array}{c}- \\
2.26 \\
0\end{array}$ & 0.024 & & & \\
\hline
\end{tabular}


Iranian Journal of Finance, 2021, Vol. 5, No. 4 (Bazraei, M.)

\begin{tabular}{|c|c|c|c|c|c|c|c|c|c|c|c|c|c|}
\hline \multirow{4}{*}{ ن̃ } & $\theta 1$ & $\begin{array}{c}0.00 \\
6\end{array}$ & $\begin{array}{c}0.30 \\
0\end{array}$ & 0.767 & $\begin{array}{l}0.0 \\
17 \\
\end{array}$ & $\begin{array}{c}2.12 \\
0\end{array}$ & 0.034 & $\begin{array}{l}0.0 \\
07\end{array}$ & $\begin{array}{c}3.72 \\
0\end{array}$ & 0.000 & $\begin{array}{l}0.0 \\
07\end{array}$ & $\begin{array}{c}3.61 \\
0\end{array}$ & $\begin{array}{l}0.0 \\
00\end{array}$ \\
\hline & $\theta 2$ & $\begin{array}{c}0.88 \\
0\end{array}$ & $\begin{array}{c}3.25 \\
0\end{array}$ & 0.001 & $\begin{array}{c}0.8 \\
90\end{array}$ & $\begin{array}{c}13.9 \\
60\end{array}$ & 0.000 & $\begin{array}{l}0.9 \\
91\end{array}$ & $\begin{array}{c}266 . \\
500\end{array}$ & 0.000 & $\begin{array}{c}0.9 \\
90\end{array}$ & $\begin{array}{l}397 . \\
300\end{array}$ & $\begin{array}{l}0.0 \\
00\end{array}$ \\
\hline & $\theta 2$ & $\begin{array}{c}0.12 \\
0\end{array}$ & $\begin{array}{c}0.75 \\
0\end{array}$ & 0.456 & & & & $\begin{array}{l}0.0 \\
06\end{array}$ & $\begin{array}{c}1.19 \\
0\end{array}$ & 0.234 & & & \\
\hline & $\lambda$ & $\begin{array}{c}2.54 \\
2\end{array}$ & $\begin{array}{c}11.3 \\
80\end{array}$ & 0.000 & $\begin{array}{c}2.5 \\
51\end{array}$ & $\begin{array}{c}11.6 \\
60\end{array}$ & 0.000 & $\begin{array}{l}4.2 \\
29\end{array}$ & $\begin{array}{c}15.5 \\
40\end{array}$ & 0.000 & $\begin{array}{l}4.1 \\
70\end{array}$ & $\begin{array}{c}15.9 \\
00\end{array}$ & $\begin{array}{l}0.0 \\
00\end{array}$ \\
\hline \multicolumn{2}{|c|}{ Akaike } & $\begin{array}{c}10.0 \\
72\end{array}$ & & $\begin{array}{c}10.06 \\
4\end{array}$ & & & $\begin{array}{c}10.05 \\
19\end{array}$ & & & $\begin{array}{c}10.04 \\
5\end{array}$ & & & \\
\hline \multicolumn{2}{|c|}{ Schwarz } & $\begin{array}{c}10.2 \\
38\end{array}$ & & $\begin{array}{c}10.20 \\
7\end{array}$ & & & $\begin{array}{c}10.17 \\
58\end{array}$ & & & $\begin{array}{c}10.15 \\
3\end{array}$ & & & \\
\hline \multicolumn{2}{|c|}{ Shibata } & $\begin{array}{c}10.0 \\
70\end{array}$ & & $\begin{array}{c}10.06 \\
2\end{array}$ & & & $\begin{array}{c}10.05 \\
08\end{array}$ & & & $\begin{array}{c}10.04 \\
51\end{array}$ & & & \\
\hline \multicolumn{2}{|c|}{$\begin{array}{c}\text { Hannan- } \\
\text { Quinn }\end{array}$} & $\begin{array}{c}10.1 \\
35\end{array}$ & & $\begin{array}{c}10.11 \\
8 \\
\end{array}$ & & & $\begin{array}{c}10.09 \\
78\end{array}$ & & & $\begin{array}{c}10.08 \\
58 \\
\end{array}$ & & & \\
\hline \multicolumn{2}{|c|}{ LL } & $\begin{array}{c}- \\
4455 \\
.3\end{array}$ & & $\begin{array}{c}- \\
4474 . \\
26\end{array}$ & & & $\begin{array}{c}- \\
8435 . \\
24\end{array}$ & & & $\begin{array}{c}- \\
8456 . \\
02\end{array}$ & & & \\
\hline \multicolumn{2}{|c|}{$\begin{array}{c}\mathrm{Li}^{-} \\
\text {McLeod } \\
(5)\end{array}$} & $\begin{array}{c}84.4 \\
546 \\
(0.28 \\
9)\end{array}$ & & $\begin{array}{c}79.85 \\
51 \\
(0.42 \\
0)\end{array}$ & & & $\begin{array}{c}39.96 \\
8 \\
(0.99 \\
)\end{array}$ & & & $\begin{array}{c}37.50 \\
44 \\
(0.99 \\
)\end{array}$ & & & \\
\hline
\end{tabular}

Source: research findings

Table 4 indicates that in both tables $\theta_{3}$ is insignificant. It implies a symmetric correlation over the time between exchange rate and index of industries in this category. DCC results suggest that $\alpha, \beta$ coefficients are insignificant in all variables and for both crises. As result, short-term persistence $(\alpha)$ and longterm persistence $(\beta)$ is confirmed. As it is seen, $\alpha$ is less than $\beta$ for all variables. The estimated $\theta_{1}$ and $\theta_{2}$ are positive for both shocks, and significant at a $1 \%$ level. The sum of these coefficients is less than 1 , indicating symmetric dynamic conditional correlations are mean-reverting ${ }^{6}$.

Table 5. Results of DCC and ADCC parameters in EOIs

\begin{tabular}{|c|c|c|c|c|c|c|c|}
\hline & & \multicolumn{3}{|c|}{ ADCC_First crisis } & \multicolumn{2}{c|}{ ADCC_Second crisis } \\
\hline & & Coef. & $\mathrm{t}$ & prob & Coef. & $\mathrm{t}$ & prob \\
\hline \multirow{5}{*}{ Exchange rate } & $\mu$ & 0.006 & 0.904 & 0.366 & 0.010 & 1.219 & 0.223 \\
\cline { 2 - 8 } & $\varphi$ & -0.782 & -1.963 & 0.054 & -0.559 & -8.278 & 0.000 \\
\cline { 2 - 8 } & $\nu$ & 0.767 & 0.954 & 0.340 & 0.549 & 7.520 & 0.000 \\
\cline { 2 - 8 } & $\omega$ & 0.007 & 1.861 & 0.063 & 0.002 & 1.053 & 0.292 \\
\cline { 2 - 8 } & $\alpha$ & 0.223 & 2.028 & 0.043 & 0.192 & 3.254 & 0.001 \\
\cline { 2 - 8 } & $\beta$ & 0.744 & 14.680 & 0.000 & 0.776 & 14.070 & 0.000 \\
\hline
\end{tabular}

${ }^{6} \alpha+\left(\frac{\gamma}{2}\right)+\beta<1$ is satisfied for each GARCH model 
Dynamic correlation between exchange rate and the listed...

\begin{tabular}{|c|c|c|c|c|c|c|c|}
\hline & $\gamma$ & 0.118 & 0.581 & 0.561 & -0.112 & -1.825 & 0.068 \\
\hline \multirow{7}{*}{ Cement } & $\mu$ & 0.025 & 1.044 & 0.297 & -0.072 & -3.369 & 0.001 \\
\hline & $\varphi$ & 0.624 & 9.563 & 0.000 & 0.202 & 3.068 & 0.001 \\
\hline & $v$ & -0.199 & -2.330 & 0.020 & 0.192 & 3.012 & 0.003 \\
\hline & $\omega$ & 0.041 & 2.329 & 0.020 & 0.006 & 1.462 & 0.144 \\
\hline & $\alpha$ & 0.444 & 1.770 & 0.077 & 0.136 & 3.412 & 0.001 \\
\hline & $\beta$ & 0.713 & 12.880 & 0.000 & 0.917 & 27.040 & 0.000 \\
\hline & $\gamma$ & -0.769 & $\begin{array}{l}-1.669 \\
\end{array}$ & 0.095 & -0.108 & -4.198 & 0.000 \\
\hline \multirow{7}{*}{ Chemicals } & $\mu$ & 0.117 & 3.493 & 0.001 & -0.027 & -1.687 & 0.092 \\
\hline & $\varphi$ & 0.118 & 1.783 & 0.072 & 0.249 & 4.598 & 0.000 \\
\hline & $v$ & 0.221 & 1.748 & 0.081 & 0.089 & 1.653 & 0.099 \\
\hline & $\omega$ & 0.359 & 0.724 & 0.469 & 0.013 & 2.877 & 0.004 \\
\hline & $\alpha$ & 0.282 & 3.114 & 0.001 & 0.162 & 5.124 & 0.000 \\
\hline & $\beta$ & 0.723 & 5.637 & 0.000 & 0.864 & 29.780 & 0.000 \\
\hline & $\gamma$ & -0.261 & $\begin{array}{l}-1.708 \\
\end{array}$ & 0.076 & $\begin{array}{l}-0.068 \\
\end{array}$ & -2.698 & 0.007 \\
\hline \multirow{7}{*}{ Basic metals } & $\mu$ & 0.058 & 0.910 & 0.363 & -0.040 & -1.749 & 0.081 \\
\hline & $\varphi$ & 0.124 & 8.483 & 0.000 & 0.229 & 2.693 & 0.007 \\
\hline & $v$ & 0.132 & 0.747 & 0.455 & 0.027 & 0.310 & 0.756 \\
\hline & $\omega$ & 0.084 & 1.140 & 0.255 & 0.025 & 2.312 & 0.021 \\
\hline & $\alpha$ & 0.185 & 2.335 & 0.020 & 0.116 & 3.668 & 0.000 \\
\hline & $\beta$ & 0.894 & 13.230 & 0.000 & 0.897 & 30.710 & 0.000 \\
\hline & $\gamma$ & -0.185 & -2.890 & 0.003 & -0.061 & -2.769 & 0.006 \\
\hline \multirow{7}{*}{ Metal ores } & $\mu$ & -0.016 & -1.118 & 0.264 & -0.114 & -5.212 & 0.000 \\
\hline & $\varphi$ & 0.295 & 4.421 & 0.000 & 0.361 & 5.477 & 0.000 \\
\hline & $v$ & 0.007 & 0.777 & 0.438 & -0.066 & -0.951 & 0.342 \\
\hline & $\omega$ & 0.002 & 0.777 & 0.438 & 0.011 & 1.913 & 0.056 \\
\hline & $\alpha$ & 0.314 & 3.973 & 0.000 & 0.113 & 3.950 & 0.000 \\
\hline & $\beta$ & 0.682 & 8.236 & 0.000 & 0.912 & 33.510 & 0.000 \\
\hline & $\gamma$ & -0.102 & -0.530 & 0.597 & -0.072 & -3.303 & 0.001 \\
\hline \multirow{7}{*}{ Petroleum } & $\mu$ & - & - & - & 0.004 & 0.387 & 0.699 \\
\hline & $\varphi$ & - & - & - & 0.054 & 0.477 & 0.633 \\
\hline & $v$ & - & - & - & 0.222 & 2.004 & 0.045 \\
\hline & $\omega$ & - & - & - & 0.000 & 0.895 & 0.371 \\
\hline & $\alpha$ & - & - & - & 0.074 & 6.641 & 0.000 \\
\hline & $\beta$ & - & - & - & 0.886 & 59.750 & 0.000 \\
\hline & $\gamma$ & - & - & - & -0.005 & -0.232 & 0.817 \\
\hline \multirow{10}{*}{ Tile and ceramics } & $\mu$ & - & - & - & -0.069 & -3.312 & 0.001 \\
\hline & $\varphi$ & - & - & - & 0.274 & 2.929 & 0.003 \\
\hline & $v$ & - & - & - & 0.042 & 0.416 & 0.677 \\
\hline & $\omega$ & - & - & - & 0.006 & 1.709 & 0.088 \\
\hline & $\alpha$ & - & - & - & 0.185 & 3.975 & 0.000 \\
\hline & $\beta$ & - & - & - & 0.854 & 32.930 & 0.000 \\
\hline & $\gamma$ & - & - & - & -0.085 & -2.032 & 0.042 \\
\hline & $\theta 1$ & 0.037 & 1.760 & 0.079 & 0.007 & 5.891 & 0.000 \\
\hline & $\theta 2$ & 0.827 & 18.750 & 0.000 & 0.980 & 511.700 & 0.000 \\
\hline & $\theta 2$ & 0.113 & 2.715 & 0.007 & 0.007 & 2.212 & 0.027 \\
\hline
\end{tabular}


Iranian Journal of Finance, 2021, Vol. 5, No. 4 (Bazraei, M.)

\begin{tabular}{|c|c|c|c|c|c|c|}
\hline & 2.622 & 11.100 & 0.000 & 4.800 & 15.960 & 0.000 \\
\hline Akaike & 11.094 & & & 11.100 & & \\
\hline Schwarz & 11.308 & & & 11.341 & & \\
\hline Shibata & 11.091 & & & 11.096 & & \\
\hline Hannan-Quinn & 11.175 & & & 11.189 & & \\
\hline LL & -6437 & & & -14744 & & \\
\hline Li-McLeod (5) & $\begin{array}{c}181.201 \\
(0.99)\end{array}$ & & & $\begin{array}{c}168.159 \\
(0.99)\end{array}$ & & \\
\hline
\end{tabular}

Source: re arch findings

Table 5 indicates that in both tables $\theta_{3}$ is significant. It implies an asymmetric correlation over the time between exchange rate and index of industries in this category (i.e. EOIs). ADCC results suggest that $\alpha, \beta$ coefficients are significant in all variables and for both crises. As result, short-term persistence $(\alpha)$ and long-term persistence $(\beta)$ is confirmed. As it is seen, $\alpha$ is less than $\beta$ for all variables. In the first crisis, estimated $\gamma^{7}$ is negative and statistically insignificant for all variables except the exchange rat, impl ing positive residuals often increase the variance (conditional volat ty) $\mathrm{n}$ re than the negative shocks with the same magnitude. The estimated $\theta_{1}$ and $\theta_{2}$ are positive for both shocks, and statistically significant at $1 \%$ level. The sum of these coefficients is less than 1 , indicating asymmetric dynamic conditional correlations are mean-reverting.

In this section, the WSEs between the return of exchange rate and index of EOIs and IOIs are calculated separately for both crisis and non-crisis periods according to Equation 17, and the results are reported in Table 8.

Table 8. Summary of statistics for stock-exchange optimal weights in export-oriented industries

\begin{tabular}{|c|c|c|c|c|c|c|}
\hline & Cement & $\begin{array}{c}\text { Chemic } \\
\text { als }\end{array}$ & $\begin{array}{c}\text { Petrole } \\
\text { um }\end{array}$ & $\begin{array}{c}\text { Basic } \\
\text { metals }\end{array}$ & $\begin{array}{c}\text { Tile and } \\
\text { ceramics }\end{array}$ & $\begin{array}{c}\text { Metal } \\
\text { ores }\end{array}$ \\
\hline Panel A: The first crisis & 0.644 & 0.749 & - & 0.801 & - & 0.857 \\
\hline $\begin{array}{c}\text { Pre- Mean Optimal } \\
\text { Weights }\end{array}$ & 0.082 & 0.162 & - & 0.182 & - & 0.251 \\
\hline $\begin{array}{c}\text { Period Mean Optimal } \\
\text { Weights }\end{array}$ & & & & & \\
\hline
\end{tabular}

\footnotetext{
${ }^{7}$.If $\gamma$ is significant and negative, the effects of positive shocks are higher than negative shocks. If $\gamma$ is significant and positive, then the effects of negative shocks are higher than positive ones (Soori, 2018)
} 
Dynamic correlation between exchange rate and the listed...

\begin{tabular}{|c|c|c|c|c|c|c|}
\hline $\begin{array}{l}\text { The difference in } \\
\text { Optimal weights }\end{array}$ & -0.562 & -0.587 & - & -0.619 & - & -0.606 \\
\hline $\mathrm{t}$-stat difference & $193.84^{*}$ & $145.38^{*}$ & - & $156.9^{* * *}$ & - & $\begin{array}{c}138.7 \\
6^{* * *}\end{array}$ \\
\hline \multicolumn{7}{|l|}{$\begin{array}{c}\text { Panel B: The second } \\
\text { crisis }\end{array}$} \\
\hline $\begin{array}{l}\text { Pre- Mean Optimal } \\
\text { Weights }\end{array}$ & 0.648 & 0.599 & 0.786 & 0.725 & 0.694 & 0.710 \\
\hline $\begin{array}{c}\text { Period Mean Optimal } \\
\text { Weights }\end{array}$ & 0.364 & 0.345 & 0.452 & 0.393 & 0.455 & 0.446 \\
\hline $\begin{array}{l}\text { The difference in } \\
\text { Optimal weights }\end{array}$ & -0.284 & -0.254 & -0.334 & -0.333 & -0.239 & -0.264 \\
\hline $\mathrm{t}$-stat difference & $20.8^{*}$ & $19.94^{* * *}$ & $25.89^{* * *}$ & $25.97^{* * * *}$ & $16.69^{* * *}$ & $19.33^{* * *}$ \\
\hline
\end{tabular}

1) A t-test for the difference in mean optimal weights is conducted.

2) The difference is calculated from the Currency crisis period to mean minus the pre- Currency crisis mean.

$*$, **, and $* * *$ represent significance at the $10 \%, 5 \%$, and $1 \%$ levels, respectively.

Source: research findings

The results show that in both currency crises, the optimal weights of different industries during the non-crisis period is higher than 50\%, while in the crisis period, they are less than $50 \%$. Then, investors in the non-crisis period should invest more than half of a one-rial portfolio to the dollar exchange rate. Moreover, in the crisis period, they should invest less than half of a one-rial portfolio to a dollar rate, reducing the risk without any reduction in the return of the portfolio.

The optimal weights vary over time and experience a prominent change during currency crisis periods. For example, the highest weighted mean of the optimal portfolio during the first non-crisis period, i.e. 85\%, belongs to metallic minerals. Thus, for a 1000 rials portfolio, 150 rials should be invested in a stock of metallic minerals, and 850 rials in the exchange market. In the first currency crisis period, the weighted mean of the optimal portfolio in this industry was reduced to $25 \%$. In the second crisis, the highest weighted mean of the optimal portfolio is $78 \%$ and belongs to the oil production industry. And thus, for a 1000 rials portfolio, an amount of 320 rials should be invested in stock of oil products, and 780 rials in the exchange market. In the second crisis period, the weighted mean of the optimal portfolio in this industry was reduced to $45 \%$. 
Table 9. Summary of statistics for stock-exchange optimal weights in import-oriented industries

\begin{tabular}{|c|c|c|c|}
\hline & Car & Computer & Pharmaceutical \\
\hline Panel A: The first crisis & & & \\
\hline Pre-Mean Optimal Weights & 0.727 & 0.870 & 0.347 \\
\hline Period Mean Optimal Weights & 0.241 & 0.230 & 0.255 \\
\hline The difference in Optimal weights & -0.486 & -0.641 & -0.092 \\
\hline t-stat difference & $44.32^{* * *}$ & $179.87^{* * *}$ & $8.23^{* * *}$ \\
\hline Panel B: The first crisis & & & \\
\hline Pre-Mean Optimal Weights & 0.890 & 0.633 & 0.357 \\
\hline Period Mean Optimal Weights & 0.494 & 0.350 & 0.493 \\
\hline The difference in Optimal weights & -0.396 & -0.284 & 0.136 \\
\hline t-stat difference & $36.42^{* * *}$ & $18.96^{* * *}$ & $9.13^{* * *}$ \\
\hline
\end{tabular}

Source: research findings

The results indicate that in both currency crises, the optimal weights of different industries except pharmaceuticals is higher than $50 \%$ during the noncrisis period, while they are less than 50\% during the crisis period. Then, investors in the non-crisis period should invest more than half of a one-rial portfolio to the dollar exchange rate. Moreover, during the crisis period, they should invest less than half of a one-rial portfolio to dollar exchange to reduce the risk of the portfolio, without any reduction in its return.

The optimal weights of these industries also vary over time and experienced a prominent change during the currency crises periods. For example, the highest weighted mean of the optimal portfolio during the first non-crisis period, i.e. $87 \%$, belongs to the computer industry. Then, for a 1000 rials portfolio, 150 rials should be invested in stock of computer, and 870 rials in the exchange market. In the first currency crisis period, the weighted mean of the optimal portfolio in this industry was reduced to $23 \%$. In the second crisis, the highest weighted mean of the optimal portfolio is $89 \%$ and belongs to the automobile industry. And thus, for the 1000 rials portfolio, the amount of 110 rials should be invested in the stock of automobiles and 890 rials in the exchange market. In the second crisis period, the weighted mean of the optimal portfolio in this industry was reduced to $49 \%$. The notable in this industry is the optimal weight of pharmaceuticals. As such, during the second crisis period, the weighted mean of the optimal portfolio increased from $35 \%$ in the non-crisis period to $49 \%$ in the crisis period. Since this industry is perceived as an import oriented industry, the increase in exchange rate leads to an increase in its prime cost and consequently, affects the profit-making in this group 


\section{Conclusion}

The exchange rate can affect the capital market through different channels. As the scope of this study covers the correlational structure of exchange rate and the different listed industries to provide a stock-exchange portfolio with regard to the currency crisis, it is critical to pay attention to the simultaneous fluctuations between both markets. The listed industries react differently to the currency crises and it depends on their activities. In this way, export-oriented and import-oriented industries are affected directly by the currency crisis.

The results of this study confirm the existence of a symmetric correlation between import-oriented industries and exchange rates in both currency crises. As such, among these industries, pharmaceutical has the lowest value of weighted mean in the optimal portfolio during a currency crisis. Moreover, the results suggest an asymmetric correlation of export-oriented industries with exchange rates during both currency crises. As such, of these industries, the highest change of weight in the optimal portfolio is related to basic metals, implying that this industry is in good condition to reduce risk during a currency crisis.

Although there are differences in dynamics and type of the used GARCH model, the results of this study show inconsistency with the results of Nikoomaram et al (2014) who showed a lack of correlation between importoriented industries and exchange rate; however, our results are consistent with the results of Basher et al (2015). Regarding the decrease in optimal portfolio weight during the crisis, the results of this study fall in line with the results obtained from Yousaf et al (2021), Yen Hsin Lee et al (2014) and Hatami et al (2016).

Our results will be applicable in three major fields: first, as stock of different industries is listed in the capital market, identifying the correlational structure and extracting optimal weights in the listed export and importoriented and other industries is vital for stakeholders, including governance, regulatory agencies, managers and shareholders, and it can play an influential role in strategic decision making.

Second, a deep understanding of the correlation between different industries and exchange markets during currency crisis periods reveals information about aspects of fundamental financial analysis, focusing on exchange rate shocks, the missing loop of financial analyses. Finally, identification of correlation in a currency crisis is important for firms in managing stock prices, because having information on how to exchange crisis is transmitted, can be useful in choosing strategy, diversification and scenario 
analysis to reduce investment risk in different projects or to get results of financial performance and exchange rate in the form of portfolio adjustments.

In case of the currency crisis, it is suggested that investors invest in the stock of basic metals, because this industry is a pioneer in attracting currency crisis and increasing stock value of the industry through future cash flow and replacement value, and reduce the stock of pharmaceuticals and computers in their portfolio, due to attracting negative effects of the exchange market.

Regarding the applicability of the present study and its wide research scope, it is recommended to the future researchers:

1- Test the correlation between exchange rate and investment industries, banking and multidisciplinary industries; this test reveals the magnitude and reaction of other industries to the given currency crisis and estimates the model of stock-exchange optimal weight in these industries. Because the present firms in these industries have dedicated a percentage of their portfolio to invest in the production firms, present in the industrial index, and with an interruption are influenced by their return fluctuations.

2- Compare the results with other developed models to establish the effectiveness of each model for users.

3- As in recent years, cross hedging strategies have attracted attention to reducing future liquidity and uncontrolled diversity of future contracts, during the currency crisis for purpose of hedging, use other assets such as gold and dynamic correlation models.

4- As the source of the studied currency crises in this paper was the exchange market, the contagion of the Covid-19 crisis to the different listed industries is suggested for future studies.

\section{References}

Arago, V., \& Fernandez, M.A. (2007), "Influence of structural changes in transmission of information between stock markets: A European Empirical Stud”, Journal of Multinational Financial Management, 17(1), PP. 112-124.

Arash Habibi \& Chin Lee, 2019. "Asymmetric Effects of Exchange Rates on Stock Prices in G7 Countries," Capital Markets Review, Malaysian Finance Association, vol. 27(1), pages 19-33. 
Baillie, R. T., \& Myers, R. J. (1991). Bivariate GARCH estimation of the optimal commodity futures hedge. Journal of Applied Econometrics, 6(2), 109-124.

Basher, S. A., \&Sadorsky, P. (2016). Hedging emerging market stock prices with oil, gold, VIX, and bonds: A comparison between DCC, ADCC and GO-GARCH. Energy Economics, 54, 235-247.

Bhattacharya, B. and Mukherjee, J. (2002), "Causal relationship between the stock market and exchange rate, foreign exchange reserves and value of trade balance: a case study for India", http:/www.igidr.ac.in/money/basabi.pdf

Bollerslev, T(1990), Modeling the Coherence in Short-run Nominal Exchange Rates: a Multivariate Generalized ARCH Model, Review of Economics and Statistics, 72 .

Botshekan, M.H, Mohseni, Hossein, (2017), 'volatility spillover and dynamic conditional correlation of exchange rate in the stock index of bank group', banking and monetary research, 10 (31), 1-28.

Branson, W.H., (1983), "Macroeconomic determinants of real exchange risk", In Herring, R.J. (Ed.), Managing Foreign Exchange Risk, Cambridge University, Cambridge.

Cappiello, L., Engle, R. F., \& Sheppard, K. (2006). Asymmetric dynamics in the correlations of global equity and bond returns. Journal of Financial econometrics, 4(4), 537-572.

Dornbusch, R., Fischer, S., (1980), "Exchange rates and the current account", The American Economic Review, 70(5), pp.960-971.

Engle, R. (2002). Dynamic conditional correlation: A simple class of multivariate generalized autoregressive conditional heteroskedasticity models. Journal of Business \& Economic Statistics, 20(3), 339-350.

Elmi, Zahra; Abounouri, Esmail; Rasekhi, Saeid; Shahrazi, M.Mahdi (2014), 'effect of structural breaks in volatilities on momentum transfer and volatility spillover between gold and stock markets in Iran', quarterly of economic modeling research, 8 (26), 57-73.

Farzanegan, Elham (2018), 'hedging strategies of gold coil price: comparison between ADCC, GO-GARCH and GARCH based on copula', quarterly of economic research, 23rd year, N. 75, 137-166.

Gavin, M., (1989), "The stock market and exchange rate dynamics", Journal of International Money and Finance, 8(2), pp.181-200.

Hatami, Amin, Mohammdi, Teimour, and Khodadadkhashi, Farhad and Abolhassani hastiani, Asghar (2018). Dynamics of hedging optimal ratio in sock and gold markets of Iran: VAR-DCC-GARCH approach. Journal of the financial economy, 12 (45) 73-92. 
Heidari, Hassan; Bashiri, Sahar, (2012), 'investigating the relationship between volatilities of real exchange rate and stock price index in Tehran Stock Exchange: pieces of evidence based on VAR-GARCH model' quarterly of economic modeling research, 3 (9), 71.

Huisman, R., Mahieu, R., Schlichter, F. (2009). Electricity portfolio management: Optimal peak/offpeak allocations, Energy Economics, 31(1), 169-174.

Inclan, C., and Tiao, G.C. (1994) 'Use of cumulative sums of squares for retrospective detection of changes of variance', Journal of the American Statistical Association, 89(427), pp.913-923

Jahangiri, Khalil; Hekmati, Farid, Samad (2015), ' a study on effects of volatility spillover in stock, gold, oil and exchange markets', quarterly of economic research, 15th year, N. 55, 159-192.

Kang, S.H., \& Cheong C., \& Yoon, S.M. (2011), "Structural changes and volatility transmission in crude oil markets", Physical A, 390(4), PP. 4317-4324.

Karimi, Mojtaba; Sarraf, Fatemeh; Emamverdi, Ghodratollah\&Baghani, Ali (2020). Identifying path of Global Financial Crisis Contagion Direction on Industries of Iran Stock Market. Iranian Journal of Finance, 4(1), 25-54.

Kroner, K. F., \& Sultan, J. (1993). Time-varying distributions and dynamic hedging with foreign currency futures. Journal of financial and quantitative analysis, 28(4), 535-551.

Ku, Y. H. H., Chen, H. C., \& Chen, K. H. (2007). On the application of the dynamic conditional correlation model in estimating optimal time-varying hedge ratios. Applied Economics Letters, 14(7),503-509.

Lee, Yen-Hsien, Huang, Ya-Ling \& Wu, Chun-Yu. (2014), Dynamic Correlations and Volatility Spillovers between Crude Oil and Stock Index Returns: The Implications for Optimal Portfolio Construction, International Journal of Energy Economics and Policy, Vol. 4, No. 3, pp:327-336

Malik, F., \& Ewing, B. T., \& Payne, J. E. (2005), "Measuring volatility persistence in the presence of sudden changes in the variance of Canadian stock return", Canadian Journal of Economics, 38(4), PP. 1037-1056.

Md Akhtaruzzaman, Sabri Boubaker \&Ahmet Sensoy.(2021), Financial contagion during COVID-19 crisis, Finance Research Letters, Volume 38,101604.

Nikoumaram, Hashem; Pourzamami, Zahra; Dehghan, Abdolmajid, (2014), 'contagious volatility in Iranian capital market', scientific- research quarterly of investing knowledge, Iran Financial Engineering Association, 3rd year, N. 15, 179-199.

Saleh, Gehan. (2008). The Dynamic Relation Between Stock Prices and Exchange Rates in Egypt, Saudi Arabia and UAE, PhD Thesis in Economics. The 
University of Illinois at Chicago.

Sanso, A., \&Arago, V., \& Carrion, J.Ll. (2003), "Testing for changes in the unconditional variance of financial time series", Revista de EconomíaFinanciera, 4(4), PP. 32-53.

Simona Moagăr-Poladian \&DorinaClichici\& Cristian-ValeriuStanciu, 2019. "The Co_movement of Exchange Rates and Stock Markets in Central and Eastern Europe," Sustainability, MDPI, Open Access Journal, vol. 11(14), pages 1-22, July.

Sosa, Miriam \& Ortiz, Edgar \& Cabello, Alejandra. (2018). Dynamic Linkages between Stock Market and Exchange Rate in MILA Countries: A Markov Regime Switching Approach (2003-2016). Revista de AnalisisEconomico. Núm. 83, vol. XXXIII.

Stock exchange, Tehran Stock Exchange (TSE), http://www.tse.ir

Wang, K. M., \& Lee, Y. M. (2016). Hedging exchange rate risk in the gold market: A panel data analysis. Journal of Multinational Financial Management, 35, 1-23.

Yao, Z., Wu, H. (2012). Financial Engineering Estimation of Minimum Risk Hedge Ratio, Systems Engineering Procedia, 3, 187-193.

Yousaf, Imran, Elie Bouri, Shoaib Ali, \& Nehme Azoury. (2021). Gold against Asian Stock Markets during the COVID-19 Outbreak. Journal of Risk and Financial Management 14: 186.

\section{Bibliographic information of this paper for citing:}

Bazraei, Maryam; Ghavidel, Salleh; Emamverdi, Ghodratollah \& Mahmoudzadeh, Mahmoud (2021). Dynamic correlation between exchange rate and the listed industries stock index during the currency crises: The Implications for Optimal Portfolio Construction. Iranian Journal of Finance, 5(4), 25-51.

Copyright @ 2021, Maryam Bazraei, Salleh Ghavidel, Ghodratollah Emamverdi and Mahmoud Mahmoudzadeh

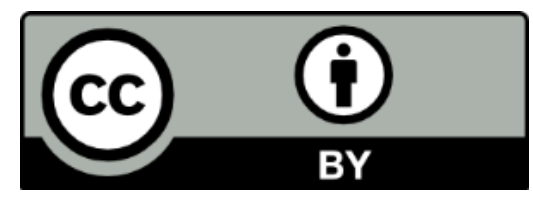

